\title{
Hepatoprotective activity of the ethanolic extract of Morus indica roots from Indian Bodo tribes
}

\author{
Hankhray Boro ${ }^{1}$. Talambedu Usha ${ }^{2}$ - Dinesh Babu ${ }^{3}$. Prakashmurthy Chandana ${ }^{4}$. Arvind Kumar Goyal ${ }^{1}$. \\ Hemavathy Ekambaram ${ }^{4} \cdot$ Hasan Soliman Yusufoglu ${ }^{5}$. Sandeep Das ${ }^{1}$. Sushil Kumar Middha ${ }^{4}(1)$
}

Received: 3 June 2021 / Accepted: 2 November 2021

Published online: 04 January 2022

(c) The Author(s) 2022 OPEN

\begin{abstract}
The roots of Morus species are well described in the Pharmacopoeia of the People's Republic of China (ChP) for its traditional use in treating liver fibrosis due to its hepatoprotective property. However, little is known about the hepatoprotective effect of the roots of Morus indica $\mathrm{L}$. (RoMi), and the pharmacological mechanism(s) are uncertain due to its intricacy. Therefore, this study evaluates the hepatoprotective activity of the ethanolic extract of RoMi (eRoMi) against the $\mathrm{CCl}_{4}$-induced in-vivo animal model at different dosages (100 and $200 \mathrm{mg} / \mathrm{kg} \mathrm{BW}$ ) in comparison with silymarin as a positive control. The hepatoprotective activity of eRoMi was evaluated by measuring the levels of serum biomarkers, hepatic antioxidant enzymes and was verified by histological studies. Interestingly, 1,2-bis(trimethylsilyl) benzene, 1,4-phenylenebis (trimethylsilane), 2,4,6-cycloheptatriene-1-one, 3,5-bis-trimethylsilyl and a-amyrin were the active components found in eRoMi as detected by GC-MS. Oral administration of eRoMi ( $200 \mathrm{mg} / \mathrm{kg} \mathrm{BW}$ ) to rats significantly protected serum biochemical parameters (increased ALT, AST, LDH, bilirubin and GGT as well as depletion of antioxidant enzymes and hepatic GSH) and elevation in hepatic lipid peroxidation as compared to $\mathrm{CCl}_{4}$-treated rats. The hematological indices such as erythrocytes, hemoglobin, monocytes and lymphocytes were also normal in eRoMi-treated rats. The histopathological evaluation indicated a significant restoration of liver structure as compared to silymarin. This study is the first scientific validation for the traditional use of eRoMi to understand its hepatoprotective activity.
\end{abstract}

Keywords Morus indica L. · Mulberry $\cdot$ Polyphenols $\cdot$ Hepatoprotective $\cdot$ Glutathione metabolism

\section{Introduction}

Hepatotoxicity or liver damage is characterized by metabolic dysfunction and histopathological patterns such as neoplasms, vascular lesions, granuloma, steatosis, cholestasis, hepatitis, and zonal necrosis, which represents
$5 \%$ of all injuries, making it frequent to known injury. As a consequence, there are more than a million casualties reported in a year, which are indirectly due to liver disfigurement or hepatocellular carcinoma [1]. Conventional or synthetic drugs protect us from various external and internal ailments. Unfortunately, the drugs used to treat

Supplementary Information The online version contains supplementary material available at https://doi.org/10.1007/s42452-02104859-z.

$\triangle$ Sushil Kumar Middha, drsushilmiddha@gmail.com | ${ }^{1}$ Department of Biotechnology, Bodoland University, Kokrajhar, Assam 783370 , India. ${ }^{2}$ Department of Biochemistry, Bangalore University, Bengaluru, Karnataka 560029, India. ${ }^{3}$ Katz Group-Rexall Centre for Pharmacy and Health Research, University of Alberta, Edmonton, AB T6G 2E1, Canada. ${ }^{4}$ Department of Biotechnology, Maharani Lakshmi Ammanni College for Women, Bangalore 560012, India. ${ }^{5}$ Department of Pharmacognosy and Pharmaceutical Chemistry, College of Dentistry and Pharmacy, Buraydah Private Colleges, P.O. Box 31717, Buraydah 51418, Kingdom of Saudi Arabia. 
liver diseases are dis-satisfactory because they do not offer complete protection to the organ and can exert serious long-term side effects [2-5]. Therefore, it is crucial to understand the role of complementary and alternative medicine (CAM) as an alternative to cure liver damage $[6$, 7]. CAM is understood to have satisfactory clinical efficacy with low adverse side effects due to its richness in polyphenols $[8,9]$. Hence, food rich in plant polyphenols may assist in slimming down the threat of chronic ailments [5, 10-14].

Morus indica L. (commonly known as mulberry) is one of the various Morus species belonging to the family Moraceae. It is evidenced for its traditional uses in the Chinese Pharmacopoeia $1985[15,16]$ and Indian traditional medicinal system (Ayurveda) for its hepatoprotection/ anti-hepatotoxicity and various other pharmacological properties. Notably, da Silva Almeida et al. [15] mentioned that the Chinese Pharmacopoeia 1985 had listed the roots and other parts of the mulberry plant as having medicinal properties. Chopra et al. [17] first documented the traditional uses of the crude drug "Sohakuhi", prepared from the root bark of certain species of Morus, followed by Konno et al. [18] in their report as an antitussive, diuretic, expectorant and tonic in oriental medicine. Chatterjee et al. [19] indicated the anti-inflammatory and antipyretic activities of $M$. indica. The root barks of Morus plants are generally called as Sang-Bai-Pi in Chinese and used for the treatment of hepatotoxicity, inflammatory and respiratory diseases [20].

The leaves of $M$. indica were identified to protect pancreatic $\beta$-cell destruction in streptozotocin (STZ)-induced diabetic male Wistar rats [21]. Natić et al. [22] reported that phenolics in Morus alba L. mainly contain caffeic acid, ferulic acid, flavonol glycosides, flavan-3-ols, $p$-coumaric acid, and protocatechuic acid. Recent studies showed that novel compounds including polyhydroxylated alkaloids, (2R,3R,4R)-2-hydroxymethyl-3,4-dihydroxypyrrolidine-Npropionamide and 4-O-a-D-galactopyranosyl-calystegine $B_{2}$, and $3 \beta, 6 \beta$-dihydroxynortropane have been isolated from the root extracts of $M$. indica using ion-exchange resins by column chromatography technique $[23,24]$. Previously, several studies involving Morus species like Morus alba L., Morus indica L., and Morus nigra were reported to show hepatoprotective activity [25-27]. Notably, compounds like 2,5-dihydroxy-4,3'-di( $\beta$-D-glucopyranosyloxy)trans-stilbene and mulberroside $A$ found in Morus plant extracts have been shown to exert hepatoprotective effects, with the latter showing P-glycoprotein inhibitory effects $[20,28]$.

However, to the best of our knowledge, there is no proper scientific evidence available on the hepatoprotective activity of the roots of $M$. indica (RoMi). Therefore, the aim of this study was to investigate the hepatoprotective activity of the ethanolic extract of RoMi (eRoMi) in carbon tetrachloride $\left(\mathrm{CCl}_{4}\right)$-induced hepatic damage in rats. In addition, the qualitative and quantitative levels of the components of eRoMi were explored using Gas chromatography coupled with mass spectrometry (GC-MS) in this study.

\section{Materials and methods}

\subsection{Chemical and reagents}

Acetic acid $\left(\mathrm{CH}_{3} \mathrm{COOH}\right)$, butanol $\left(\mathrm{C}_{4} \mathrm{H}_{9} \mathrm{OH}\right)$, bovine serum albumin (BSA), di-potassium hydrogen phosphate $\left(\mathrm{K}_{2} \mathrm{HPO}_{4}\right), \mathrm{EDTA}$, eosin, epinephrine, formalin, hematoxylin, hydrogen peroxide $\left(\mathrm{H}_{2} \mathrm{O}_{2}\right)$, potassium di-hydrogen phosphate $\left(\mathrm{KH}_{2} \mathrm{PO}_{4}\right)$, sodium carbonate $\left(\mathrm{Na}_{2} \mathrm{CO}_{3}\right)$, sodium bicarbonate $\left(\mathrm{NaHCO}_{3}\right)$, ethanol $\left(\mathrm{C}_{2} \mathrm{H}_{5} \mathrm{OH}\right)$, thiobarbituric acid (TBA), tetramethoxypropane, sodium dodecyl sulphate (SDS), Triton- $X 100$ and pyridine were procured from Merck, Mumbai, India. Bradford reagent, glutathione (GSH) reductase, nicotinamide, epinephrine, reduced GSH and tert-butyl hydroperoxide were bought from Sigma-Aldrich, India. Silymarin was procured from an indigenous pharmacy store, Bangalore, India.

\subsection{Collection and preparation of roots of $M$. indica (RoMi) extract}

The roots were collected from the Bishmuri Bashbari area (latitude: $26^{\circ} 33^{\prime} 42.6^{\prime \prime} \mathrm{N}$ and longitude: $90^{\circ} 16^{\prime} 17.2^{\prime \prime} \mathrm{E}$ ) in the month of April-May, 2017, Kokrajhar, Assam, India. The plant roots were identified and authenticated by Dr. A.A. Mao, B.S.I. Shillong, Meghalaya, India and deposited to B.S.I. herbarium for future reference (V.No: BSI/ERC/ Tech/Plant Iden./2015/68/Coll No. 013). The roots were oven-dried at $40^{\circ} \mathrm{C}$ for 20 days, powdered and stored in an air-tight container. The $100 \mathrm{~g}$ roots were extracted with $1000 \mathrm{ml}$ of $70 \%$ ethanol $\mathrm{v} / \mathrm{v}(70: 30)$ under nitrogen, shaken well and stored in the dark at room temperature $\left(\mathrm{RT} ; 25^{\circ} \mathrm{C}\right)$ for $48 \mathrm{~h}$. The extract was then filtered using Whatman no.42 filter paper. The extracted contents were centrifuged at $10,000 \mathrm{~g}$ for $20 \mathrm{~min}$, followed by purging with nitrogen [29]. The extract was concentrated using a Telstar LyoQuest benchtop freeze dryer and stored at $4{ }^{\circ} \mathrm{C}$ for further study.

\subsection{Gas chromatography coupled with mass spectrometry (GC-MS) analysis}

The analysis of eRoMi was performed by PerkinElmer gas chromatography (Clarus 680) coupled with mass spectrometry (Clarus $600 \mathrm{El}$ ) employed with fused silica column and packed with capillary column Elite-5MS (5\% biphenyl 
95\% dimethylpolysiloxane, $30 \mathrm{~m} \times 0.25 \mathrm{~mm}$ ID $\times 250 \mu \mathrm{m}$ df). The components were separated using Helium as carrier gas at a constant flow of $1 \mathrm{ml} / \mathrm{min}$. The injector temperature was set at $260{ }^{\circ} \mathrm{C}$ during the chromatographic run. The extract sample $(1 \mu \mathrm{l})$ was injected into the instrument with an oven temperature at $60^{\circ} \mathrm{C}(2 \mathrm{~min})$ with an increasing rate of $10^{\circ} \mathrm{C} / \mathrm{min}$ until it reached $300^{\circ} \mathrm{C}$, where it was held for $6 \mathrm{~min}$. The mass detector conditions were: transfer line temperature $240{ }^{\circ} \mathrm{C}$; ion source temperature $240^{\circ} \mathrm{C}$; and ionization mode electron impact at $70 \mathrm{eV}$, a scan time $0.2 \mathrm{~s}$ and scan interval of $0.1 \mathrm{~s}$. The fragment sizes from 40 to $600 \mathrm{Da}$ were scanned. The spectrums of the components were compared with the database of the spectrum of known components stored in the GC-MS NIST (2008) library.

\subsection{Animals and care}

Thirty healthy male Wistar albino rats weighing $210-250 \mathrm{~g}$ were used for the experiment. The animals were housed in polypropylene standard cages $(46 \times 24 \times 20 \mathrm{~cm})(T a r-$ son, India), with rice husk as bedding material, having six animals per cage in a standard environmental condition $\left(26 \pm 3{ }^{\circ} \mathrm{C}, 65 \pm 1 \%\right.$ relative humidity, and light control room with a 12-h dark/light cycle). They were allowed to acclimatize for 1-2 weeks and were fed with standard pellet feed (Lipton India Ltd., Bangalore, India) and water ad libitum. The experiments with animals were performed as per the legislation for the protection of animals used for scientific purposes.

\subsection{Ethical statement}

All the experiments were performed in strict accordance with standard guidelines accepted internationally. The ethical approval was obtained from Maharani Lakshmi Ammanni College Ethical Committee (1368/ac/10/CPCSEA), Bangalore, India for the care and use of laboratory animals.

\subsection{Acute toxicity study}

OECD guidelines (test 423: Acute oral toxicity-Acute toxic class method; 2002) were followed to study the acute toxicity of the RoMi extract (OECD Library, 2002). All the animals (12 male Wistar albino rats) were kept on fasting overnight prior to the experiment. Decreasing doses beginning with $2000 \mathrm{mg} / \mathrm{kg}$ (3 animals of each sex) were tested only when toxicity signs were observed at this limit dose. The followed concentrations were determined as per OECD guidelines. The eRoMi extract was administered orally in an increasing dose of $250,500,1000$ and $2000 \mathrm{mg} / \mathrm{kg}$ body weight (BW). After feeding of various doses of the extract, all the rats were carefully observed for the development of clinical or toxicological symptoms at $30 \mathrm{~min}$ and then at 2 , $4,8,24$ and $48 \mathrm{~h}$. Finally, rats were observed for the development of clinical or toxicological symptoms until 14 days.

\subsection{Experimental design and drug administration}

Thirty male rats were randomly divided into five groups containing six rats each. The treatment of each group is described below. $3 \mathrm{ml} / \mathrm{kg}$ of $\mathrm{CCl}_{4}$ was administered orally once on the first day. eRoMi was dissolved in Millipore water and two different concentrations $(100 \mathrm{mg} / \mathrm{kg}$ and $200 \mathrm{mg} / \mathrm{kg}$ ) of eRoMi were administered orally every day in the morning with the help of a $16 \mathrm{G}$ gavage needle while the control group was maintained on Millipore water. On the final day, before euthanization, groups 2, 3, 4 and 5 were administered with $\mathrm{CCl}_{4}$ [25]. Body weights were monitored throughout the experiment.

Group 1 was administered with Millipore water + dietary supplement served as solvent control (Control).

Group 2 was administered with $\mathrm{CCl}_{4}$ on the first day + dietary supplement served as disease-induced control $\left(\mathrm{CCl}_{4}\right)$.

Group 3 was administered with $\mathrm{CCl}_{4}$ on the first day $+100 \mathrm{mg} / \mathrm{kg} \mathrm{BW}$ of eRoMi orally + dietary supplement for 7 days (eRoMi 100).

Group 4 was administered with $\mathrm{CCl}_{4}$ on the first day $+200 \mathrm{mg} / \mathrm{kg}$ BW of eRoMi orally + dietary supplement for 7 days (eRoMi 200).

Group 5 was administered with $\mathrm{CCl}_{4}$ on the first day $+25 \mathrm{mg} / \mathrm{kg}$ BW of silymarin orally + dietary supplement for 7 days (Silymarin 25; Positive Control).

For silymarin group, Silybon-140 mg, Micro Lab Limited, India was used.

\subsection{Preparation of liver tissue samples}

On the 8th day, i.e., $24 \mathrm{~h}$ after the last treatment, all rats were weighed and euthanized under proper anesthesia using a combination of $0.15 \mathrm{ml} / 100 \mathrm{~g}$ xylazine $(30 \mathrm{mg} /$ $\mathrm{kg} \mathrm{BW})$ and $0.3 \mathrm{ml} / 100 \mathrm{~g}$ i.p ketamine $(300 \mathrm{mg} / \mathrm{kg} \mathrm{BW})$ as proposed by Committee for the Purpose of Control and Supervision of Experiments on Animals (CPCSEA). The blood was collected by retro-orbital puncture in an EDTAcontaining tube from all the experimental rats. The livers of each rat were removed, weighed and perfused in the ice-cold phosphate buffer of $\mathrm{pH}$ 7.0. A portion of the liver was preserved in $10 \%$ formaldehyde solution for histopathological evaluation and from the remaining portion, the homogenate was prepared by centrifuging at $1000 \times \mathrm{g}$ for $10 \mathrm{~min}$ at $4{ }^{\circ} \mathrm{C}$. The supernatant was collected after centrifugation and was used for in-vivo enzymatic assays [8]. 


\subsection{Measurement of serum electrolytes}

The blood was allowed to clot for $60 \mathrm{~min}$ at RT and then serum was collected by low-speed centrifugation at $120 \times \mathrm{g}$ for $5 \mathrm{~min}$. The straw-colored serum was used to study the biochemical parameters in Cobas Auto analyzer for serum electrolyte determination.

\subsection{Biochemical assays in blood}

The activities of aspartate transaminase (AST), alanine transaminase (ALT), alkaline phosphatase (ALP), gammaglutamyl transpeptidase, total bilirubin, triglycerides (TG), HDL-cholesterol, LDL-cholesterol and total cholesterol (TC) were estimated using standard AMP diagnostic kits (Graz, Austria). Liver damage was assessed by estimating the enzymatic activities of serum AST, ALT, and ALP, as well as TC, TG, and albumin levels, using the corresponding commercial kits.

\subsection{Assessment of in-vivo liver enzymatic assays}

\subsubsection{Superoxide dismutase (SOD) assay}

The SOD activity was determined by the Misra and Fredovich [30, 31] method, modified by Middha et al., [30]. A volume of $880 \mu \mathrm{l}$ of $0.05 \mathrm{M}$ carbonate buffer $(\mathrm{pH} 10.2)$ containing $0.1 \mathrm{mmol}$ EDTA and $20 \mu \mathrm{l}$ of $30 \mathrm{mmol}$ epinephrine in $0.05 \%$ acetic acid was added to the tissue extract of $100 \mu \mathrm{l}$, and changes in activity were measured at $480 \mathrm{~nm}$ for $4 \mathrm{~min}$. The activity was expressed as the amount of enzyme that inhibits the oxidation of epinephrine by $50 \%$, which is equivalent to one unit and is expressed in terms of units/mg protein.

\subsubsection{Catalase (CAT) assay}

Catalase activity was determined as described by Khan et al. [32]. The reaction solution of catalase activity contained $1 \mathrm{ml}$ of $59 \mathrm{mmol} / \mathrm{L} \mathrm{H}_{2} \mathrm{O}_{2}$ (dissolved in $50 \mathrm{mmol}$ phosphate buffer, $\mathrm{pH} 7.0$ ) and $0.1 \mathrm{ml}$ of hepatic supernatant was added to $1.9 \mathrm{ml}$ deionized water. Changes in the absorbance of the reaction solution at $240 \mathrm{~nm}$ were determined every 1 min up to 3 min (using Kinetics spectrometer). One unit of catalase activity was defined as an absorbance change of 0.01 as units $/ \mathrm{mg} / \mathrm{min}$.

\subsubsection{Glutathione peroxidase (GPx) assay}

GPx activity was measured as described by Middha et al. [33] at $37^{\circ} \mathrm{C}$. The reaction mixture consisted of $500 \mu \mathrm{l}$ of phosphate buffer, $100 \mu \mathrm{l}$ of $0.01 \mathrm{M}$ reduced glutathione (GSH), $100 \mu \mathrm{l}$ of $1.5 \mathrm{mM} \mathrm{NADPH}$ and $100 \mu \mathrm{l}$ of GR (0.24 U). $100 \mu \mathrm{l}$ of tissue extract was added to the reaction mixture and incubated at $37^{\circ} \mathrm{C}$ for $10 \mathrm{~min} .50 \mu \mathrm{l}$ of $12 \mathrm{mM}$ t-butyl hydroperoxide were added to $450 \mu$ l of the tissue reaction mixture and measured at $340 \mathrm{~nm}$ for $180 \mathrm{~s}$ in a BioSpectrometer (Eppendorf, Model BL 192). The molar absorptivity of $6.22 \times 10^{3} \mathrm{M} / \mathrm{cm}$ was used to determine enzyme activity. One unit of activity is equal to $\mu \mathrm{M}$ NADPH oxi$\mathrm{dized} / \mathrm{min} / \mathrm{mg}$ protein.

\subsubsection{Assays for measurement of reduced glutathione (GSH), oxidized glutathione (GSSG) and ratio of GSH: GSSG}

The levels of GSH were estimated using the method of Salbitani et al. [34]. A total of $1 \mathrm{ml}$ of homogenate was precipitated with $1 \mathrm{ml}$ of $4 \%$ sulfosalicylic acid. Samples were kept at $4{ }^{\circ} \mathrm{C}$ for $1 \mathrm{~h}$ and then centrifuged at $1200 \times \mathrm{g}$ for $20 \mathrm{~min}$ at $4{ }^{\circ} \mathrm{C}$. The total volume of $3 \mathrm{ml}$ assay mixture contained $0.1 \mathrm{ml}$ of a filtered aliquot of the liver homogenate, $2.7 \mathrm{ml}$ of phosphate buffer (0.1 mol; $\mathrm{pH} \mathrm{7.4)} \mathrm{and} 0.2 \mathrm{ml}$ of DTNB (100 mmol). The yellow colour that developed was read immediately at $412 \mathrm{~nm}$ on a SmartSpec ${ }^{\text {TM }}$ Plus Spectrophotometer (Bio-Rad, Hercules, CA, USA). It was expressed as $\mu \mathrm{mol} \mathrm{GSH} / \mathrm{mg}$ of the liver.

Oxidized glutathione (GSSG) level was measured by the protocol previously used by Griffith [35]. It was expressed as $\mu \mathrm{mol}$ GSSG/mg of the liver. GSH metabolism was generally calculated as the ratio of total GSH/GSSG.

\subsection{Lipid peroxidation}

Malondialdehyde (MDA), a marker of lipid peroxidation, was assessed by the method of Ohkawa et al. [37], using 1, 1, 3, 3-tetramethoxypropane as standard. Briefly, 8.1\% SDS was added to the tissue homogenate and incubated for $10 \mathrm{~min}$ at RT, followed by boiling with $20 \%$ acetic acid and $0.6 \%$ thiobarbituric acid (TBA) for $1 \mathrm{~h}$ in a water bath. After cooling, butanol: pyridine solution $(15: 1 \mathrm{v} / \mathrm{v})$ was added and the mixture was centrifuged at $600 \times \mathrm{g}$ for $5 \mathrm{~min}$. The absorbance of the upper coloured layer was measured at $532 \mathrm{~nm}$ and the concentration of MDA was expressed in terms of $\mathrm{nmol} / \mathrm{mg}$ protein.

\subsection{Total protein assay}

The total protein assay was done by the method of Lowry et al. [36], taking BSA as standard. In brief, to the supernatant of $100 \mu \mathrm{l}, 500 \mu \mathrm{l}$ of alkaline copper sulphate was added and allowed to incubate for $10 \mathrm{~min}$ at RT. 
After incubation, $60 \mu \mathrm{l}$ of diluted Folin-Ciocalteu reagent $(1: 1)$ was added and incubated for another $30 \mathrm{~min}$ at RT. Following this, absorbance was taken at $660 \mathrm{~nm}$ against the reagent blank.

\subsection{Histopathological studies}

A small portion of the liver was excised and washed with normal saline and processed separately for histopathological observation. Initially, the liver tissues were fixed in $10 \%$ buffered neutral formalin for at least $48 \mathrm{~h}$, dehydrated in gradual ethanol (50-100\%), cleared in xylene, and embedded in paraffin. The $4 \mu \mathrm{m}$ sections were prepared using a microtome. Then, the liver sections were dewaxed in xylene, rehydrated in a series of different grades of alcohol and then washed with distilled water for $5 \mathrm{~min}$. The liver sections were stained with basic stain hematoxylin for $40 \mathrm{~s}$ and counterstained with acidic stain eosin for $20 \mathrm{~s}$ (H-E) dye [30]. The sections were examined microscopically (100X and 400X) using an Olympus microscope for any histopathological changes, including cell necrosis, fatty changes and vacuolation.

\subsection{Statistical analysis}

Data were expressed as mean $\pm \mathrm{SE}$. Comparison between different groups was performed using one-way ANOVA, followed by Tukey's multiple comparison tests (GraphPad Prism, Windows 5). $p<0.05$ was considered to be statistically significant.

\section{Results}

\subsection{Total yield of the extract}

The total yield of eRoMi extract isolated from the roots of $M$. indica was found to be $5.9 \% \mathrm{w} / \mathrm{w}$.

\subsection{GC-MS compound profiling}

Figure 1 shows the chromatogram of the GC-MS profile of eRoMi extract run for $35 \mathrm{~min}$, which indicated the presence of 1,2-bis(trimethylsilyl) benzene, 1,4-phenylenebis (trimethylsilane), 2,4,6-cycloheptatriene-1-one, 3,5-bis-trimethylsilyl, and a-amyrin at retention times (RT) of 30.609, $30.674,31.035$ and 31.745, respectively (Table 1, Fig. 1).

\subsection{Acute toxicity study}

No fatality was observed following the oral administration of eRoMi to the investigational animals at $2000 \mathrm{mg} / \mathrm{kg} \mathrm{BW}$ dose. Therefore, $1 / 10 \mathrm{th}(200 \mathrm{mg} / \mathrm{kg})$ of the maximum dose and $1 / 20$ th $(100 \mathrm{mg} / \mathrm{kg})$ were considered safe for the invivo studies. No signs of clinical or toxicological symptoms in experimental animals were observed after 14 days.

\subsection{Effect of eRoMi on hematological parameters}

The effects of administration of eRoMi on the hematological parameters are shown in Table S-1. Compared
Fig. 1 The chromatogram of the GC-MS profile of eRoMi extract run for $35 \mathrm{~min}$ (showing the different peaks with retention times)

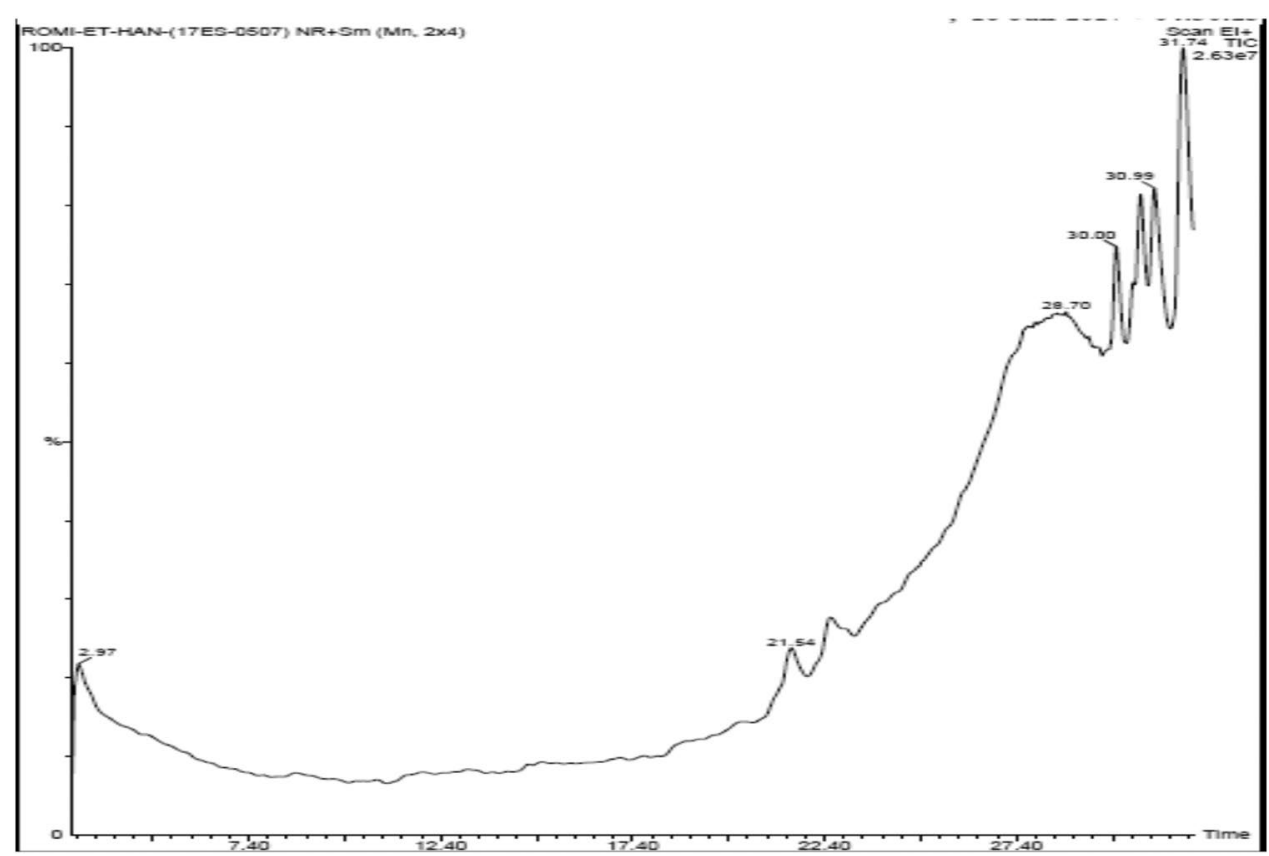

SN Applied Sciences A SPRINGer Nature journal 
Table 1 Major bioactive compounds identified by the GC-MS analysis of ethanolic root extracts of Morus indica L

\begin{tabular}{|c|c|c|c|c|c|c|c|}
\hline S. No & Compound Name & Structure & Molecular Formula & $\begin{array}{l}\text { M.W } \\
(\mathrm{g} / \mathrm{mol})\end{array}$ & $\mathrm{RT}$ (min) & Peak Area (\%) & Pharmacological Activity \\
\hline 1 & $\begin{array}{l}\text { 1,2-Bis(trimethylsilyl) } \\
\text { benzene } \\
\text { (CAS: 17151-09-6) }\end{array}$ & & $\mathrm{C}_{12} \mathrm{H}_{22} \mathrm{Si}_{2}$ & 222.47 & 30.609 & 6.953 & - \\
\hline 2 & $\begin{array}{l}\text { 1,4-Phenylenebis } \\
\text { (trimethylsilane) } \\
\text { (CAS: 13183-70-5) }\end{array}$ & & $\mathrm{C}_{12} \mathrm{H}_{22} \mathrm{Si}_{2}$ & 222.47 & 30.674 & 5.191 & - \\
\hline 3 & $\begin{array}{l}\text { 2,4,6-Cycloheptatrien- } \\
\text { 1-one, 3,5-bis- } \\
\text { trimethylsilyl- } \\
\text { (CAS: } 900161-21-8 \text { ) }\end{array}$ & & $\mathrm{C}_{13} \mathrm{H}_{22} \mathrm{OSi}_{2}$ & 250.48 & 31.035 & 27.563 & - \\
\hline 4 & $\begin{array}{l}\text { a-Amyrin } \\
\text { (CAS: 638-95-9) }\end{array}$ & & $\mathrm{C}_{30} \mathrm{H}_{50} \mathrm{O}$ & 426.72 & 31.745 & 54.594 & $\begin{array}{l}\text { Anti-inflammatory, } \\
\text { three times more potent } \\
\text { than aspirin, antidia- } \\
\text { betic, anti-arthritis and } \\
\text { anticancer [38] }\end{array}$ \\
\hline
\end{tabular}

with the control group, the disease-induced group that received $\mathrm{CCl}_{4}$ showed a decline in the levels of erythrocytes, hemoglobin, mean corpuscular volume (MCV), mean corpuscular hemoglobin concentration (MCHC), and monocytes, whereas the levels of leukocytes, lymphocytes and mean corpuscular hemoglobin $(\mathrm{MCH})$ were noted to be increased. Results show that there were no statistically significant changes in erythrocyte count, hemoglobin, leukocytes and MCHC values of groups treated with eRoMi when compared with control and Silymarin groups. The extract caused a significant reduction in $\mathrm{MCH}$ and lymphocytes by 1.1 and 1.5 folds, respectively $(p<0.05)$. Monocytes were also found to be increased as compared with that of the control group $(p<0.05)$.

\subsection{Effect of eRoMi on biochemical parameters}

\subsubsection{Effect of eRoMi on the indices of hepatotoxicity based on liver marker enzymes}

Administration of $\mathrm{CCl}_{4}$ markedly increased the levels of serum hepatic enzymes such as ALT, AST and ALP in the disease-induced group as compared to the control group (Table 2). The increase in these enzyme activities was significantly decreased with the treatment of eRoMi; the high concentration group of eRoMi $(200 \mathrm{mg} / \mathrm{kg})$ showing better results than the low concentration $(100 \mathrm{mg} / \mathrm{kg})$.

\subsubsection{Effect of eRoMi on TC, TG, HDL, LDL, and VLDL levels}

The administration of $\mathrm{CCl}_{4}$ has increased TC $(6.40 \pm 0.02 \mathrm{mmol} / \mathrm{L}), \mathrm{TG}(1.78 \pm 0.01 \mathrm{mmol} / \mathrm{L}), \mathrm{LDL}$ $(162.00 \pm 10.81 \mathrm{mg} / \mathrm{dL})$, and VLDL $(29.01 \pm 0.87 \mathrm{mg} / \mathrm{dL})$, and decreased HDL $(27.11 \pm 1.42 \mathrm{mg} / \mathrm{dL})$; whereas in the groups that received silymarin and test extract eRoMi, the levels of TC, TG, LDL and VLDL have significantly decreased with increase in HDL levels (Table S-2). A high concentration of eRoMi showed better results when compared with the low concentration group. The major fold changes were seen in VLDL ( 0.80 fold) followed by TG $(0.77$ fold), TC ( 0.76 fold) and LDL ( 0.67 fold) after the treatment with the high dose of eRoMi as compared to the $\mathrm{CCl}_{4}$-treated animals. The level of HDL increased with the administration of eRoMi and showed better result at high concentration $(34.20 \pm 2.83 \mathrm{mg} / \mathrm{dL})$ compared to low concentration $(29.12 \pm 0.39 \mathrm{mg} / \mathrm{dL})$. These results of high-dose treatment were comparable with the standard drug silymarin, which was effective in reverting biochemical parameters in diseased animals.

\section{SN Applied Sciences}


Table 2 Biochemical parameters of animals in blood of the control and treatments

\begin{tabular}{lccccc}
\hline & Control & $\mathrm{CCl}_{4}$ & Silymarin $(25 \mathrm{mg} / \mathrm{kg})$ & eRoMi $(100 \mathrm{mg} / \mathrm{kg})$ & eRoMi $(200 \mathrm{mg} / \mathrm{kg})$ \\
\hline Albumin $(\mathrm{g} / \mathrm{dL})$ & $39.14 \pm 1.21$ & $25.70 \pm 1.76 \mathrm{a}$ & $29.60 \pm 1.98 \mathrm{~b}$ & $26.02 \pm 1.90 \mathrm{a}$ & $30.25 \pm 0.25 \mathrm{~b}$ \\
ALT (U/L) & $26.50 \pm 0.98$ & $118.00 \pm 9.43 \mathrm{a}$ & $88.10 \pm 9.31 \mathrm{~b}$ & $108.30 \pm 11.42 \mathrm{a}$ & $66.33 \pm 4.73 \mathrm{~b}$ \\
AST (U/L) & $27.50 \pm 1.31$ & $208.00 \pm 24.94 \mathrm{a}$ & $98.20 \pm 10.21 \mathrm{~b}$ & $149.67 \pm 11.93 \mathrm{c}$ & $101.33 \pm 11.2 \mathrm{c}$ \\
Total Protein (g/dL) & $6.16 \pm 0.23$ & $5.98 \pm 0.11 \mathrm{a}$ & $6.11 \pm 0.34 \mathrm{~b}$ & $6.09 \pm 0.05 \mathrm{~b}$ & $6.13 \pm 0.17 \mathrm{~b}$ \\
ALP (U/L) & $14.00 \pm 0.45$ & $27.00 \pm 1.20 \mathrm{a}$ & $15.50 \pm 08 \mathrm{~b}$ & $22.33 \pm 2.52 \mathrm{~b}$ & $21.00 \pm 1.31 \mathrm{a}$ \\
Urea (mg/dL) & $22.75 \pm 1.05$ & $34.12 \pm 1.21 \mathrm{a}$ & $28.63 \pm 1.43 \mathrm{~b}$ & $30.31 \pm 3.12 \mathrm{~b}$ & $28.91 \pm 2.08 \mathrm{~b}$ \\
Creatinine $(\mathrm{mg} / \mathrm{dL})$ & $0.68 \pm 0.01$ & $0.79 \pm 0.01 \mathrm{a}$ & $0.70 \pm 0.01 \mathrm{~b}$ & $0.77 \pm 0.02 \mathrm{a}$ & $0.71 \pm 0.04 \mathrm{~b}$ \\
\hline
\end{tabular}

*Values are mean \pm S.E. ( $n=6$ animals /group). Statistical analysis was done by one-way ANOVA between groups and values were considered significant at $p<0.05$. Those which are not sharing the same letters are significantly different. ALT: Alanine aminotransferase; AST: Aspartate aminotransferase; ALP: Alanine phosphatase; TC: Total Cholesterol; TG: Triglyceride; HDL: High-density lipoproteins; LDL: Low-density lipoproteins; VLDL:Very-low-density lipoproteins; GGT: $\gamma$-glutamyl transferase

\subsubsection{Effect of eRoMi on serum urea and creatinine}

The serum biochemical assay of the current investigation has been tabulated in Table 2 . In the control group, creatinine and urea levels were noted to be $0.68 \pm 0.01 \mathrm{mg} / \mathrm{dL}$ and $22.75 \pm 1.05 \mathrm{mg} / \mathrm{dL}$, respectively. $\mathrm{CCl}_{4}$ administration significantly increased the urea $(34.12 \pm 1.21 \mathrm{mg} / \mathrm{dL})$ and plasma creatinine $(0.79 \pm 0.01 \mathrm{mg} / \mathrm{dL})$ levels as compared to the control group. Treatment with $\mathrm{CCl}_{4}$ advanced the creatinine and urea levels by almost 1.2 and 1.5 folds. When the experimental rats were treated with the standard drug silymarin and different doses of eRoMi, it was noticed that in the case of silymarin, the creatinine and urea levels almost clocked back to the normal. Upon treatment with eRoMi, the high dose was found to be more effective in decreasing these creatinine and urea levels than the low dose, being statically significant in both cases.

\subsubsection{Effect of eRoMi on total protein and albumin}

As shown in Table 2, $\mathrm{CCl}_{4}$ administration decreased the albumin (to $65.6 \%, p<0.05$ ) and total protein levels as compared to the control, although the decrease in total protein was not significant. The albumin was decreased. Treatment with eRoMi at a high dose $(200 \mathrm{mg} / \mathrm{kg})$ and silymarin significantly increased the albumin to $77.3 \%$ and $75.6 \%$, respectively, as compared to the control. There were no significant changes $(p<0.05)$ in the total protein levels in the treatment groups compared to the control group.

\subsubsection{Effect of eRoMi on bilirubin and gamma-glutamyl transpeptidase (GGT)}

The administration of $\mathrm{CCl}_{4}$ elevated the levels of serum bilirubin (313.3\%) and GGT (262.0\%) as compared to the control group (Table S-2). After the treatment of eRoMi, bilirubin was lessened to $251.7 \%$ (with $100 \mathrm{mg} / \mathrm{kg}$ eRoMi), $215.0 \%$ (with $200 \mathrm{mg} / \mathrm{kg}$ eRoMi) and $181.7 \%$ (with silymarin); whereas GGT was reduced to $199.0 \%$ (with $100 \mathrm{mg} /$ $\mathrm{kg}$ eRoMi), 197.1\% (with $200 \mathrm{mg} / \mathrm{kg}$ eRoMi), and silymarin (150.3\%) as compared to control.

\subsection{Effect of eRoMi on plasma electrolytes levels}

The sodium $\left(\mathrm{Na}^{+}\right)$, potassium $\left(\mathrm{K}^{+}\right)$and chloride $\left(\mathrm{Cl}^{-}\right)$levels were found to be increased by $8.3 \%, 16.9 \%$, and $6.8 \%$, respectively, in the $\mathrm{CCl}_{4}$ group animals compared to control group animals (Table 3). After treatment with the test extract eRoMi, the $\mathrm{Na}^{+}, \mathrm{K}^{+}$, and $\mathrm{Cl}^{-}$levels were found to be decreased when compared to $\mathrm{CCl}_{4}$-treated animals; however, the changes were not significant $(p<0.05)$.

\subsection{Effect of eRoMi on the parameters of oxidative stress in liver}

\subsubsection{Effect of eRoMi on antioxidant enzymes SOD, CAT, and GPx}

The administration of $\mathrm{CCl}_{4}$ resulted in a significant decrease in activities of antioxidant enzymes such as CAT, SOD and GPx in the liver as compared to the control (Fig. 2a, b and c). The activities of CAT, SOD and GPx were decreased by $26.38 \%, 3.72 \%$ and $62.10 \%$, respectively. The groups treated with eRoMi at two different doses and silymarin significantly increased $(p<0.05)$ the activities of the enzymes as compared to the $\mathrm{CCl}_{4}$-treated group, and the protective effect of eRoMi treatment at $200 \mathrm{mg} / \mathrm{kg}$ was similar to that of silymarin treatment.

\subsubsection{Effect of eRoMi on the activity of GSH, GSSG and GSH metabolism}

The administration of $\mathrm{CCl}_{4}$ reduced the $\mathrm{GSH}$ level by $27.2 \%$ as compared to the control group (Fig. 2d). The GSH level 
Table 3 Effect of eRoMi on plasma electrolytes levels

\begin{tabular}{lcccrr}
\hline & Control & $\mathrm{CCl}_{4}$ & Silymarin $(25 \mathrm{mg} / \mathrm{kg})$ & \multicolumn{1}{l}{$\begin{array}{l}\text { eRoMi } \\
(100 \mathrm{mg} / \mathrm{kg})\end{array}$} & $\begin{array}{l}\text { eRoMi } \\
(200 \mathrm{mg} / \mathrm{kg})\end{array}$ \\
\hline Sodium (mmol/L) & $139.14 \pm 11.32$ & $150.7 \pm 12.3 \mathrm{a}$ & $146.6 \pm 11.42 \mathrm{a}$ & $6.02 \pm 11.49 \mathrm{a}$ & $141.25 \pm 12.41 \mathrm{a}$ \\
Potassium (mmol/L) & $5.9 \pm 1.42$ & $6.90 \pm 1.32 \mathrm{a}$ & $6.10 \pm 1.43 \mathrm{~b}$ & $6.80 \pm 1.01 \mathrm{a}$ & $6.56 \pm 0.85 \mathrm{a}$ \\
Chloride (mmol/L) & $101.10 \pm 11.65$ & $108 \pm 9.04 \mathrm{a}$ & $103.2 \pm 9.69 \mathrm{a}$ & $106.67 \pm 8.93 \mathrm{a}$ & $104.33 \pm 7.98 \mathrm{a}$ \\
\hline
\end{tabular}

Statistical analysis revealed that there are no significant differences between the groups.

*Values are mean \pm S.E. ( $n=6$ animals /group). Statistical analysis was done by one-way ANOVA between groups and values were considered significant at $p<0.05$. Those which are not sharing the same letters are significantly different
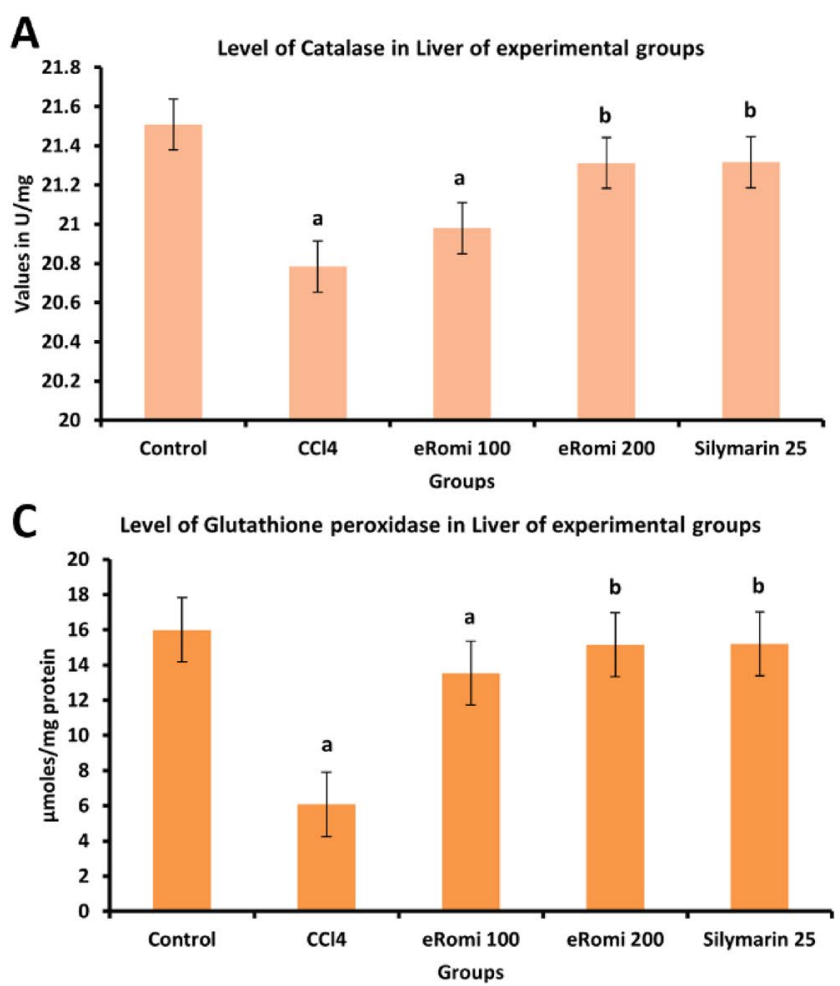

Fig. 2 Effect of eRoMi on the levels of a Catalase, $\mathbf{b}$ Superoxide dismutase, c Glutathione Peroxidase and d GSH and GSSG. Values are mean \pm S.E. ( $n=6$ animals per group). Statistical analysis was done

was ameliorated upon treatment with eRoMi at both doses and was comparable to the effect of treatment with silymarin.

The GSH/GSSG ratio was decreased in $\mathrm{CCl}_{4}$-treated rats when compared to control rats $\left(1.372 \pm 0.2\right.$ for $\mathrm{CCl}_{4}$ versus $0.856 \pm 0.1$ for control; $p \leq 0.05$ ) (Fig. 3 ). The alteration in $\mathrm{GSH}$ metabolism caused by $\mathrm{CCl}_{4}$ treatment was prevented when experimental rats were supplemented with eRoMi. eRoMi $200(1.09 \pm 0.1)$ was more effective than the other group except standard drug silymarin $25(1.17 \pm 0.3)$. Consequently, a significant decrease was noticed in the GSSG level in the eRoMi 200 group, when compared with the $\mathrm{CCl}_{4}$-treated group (Fig. 2d).
B Level of Superoxide dismutase in Liver of experimental groups

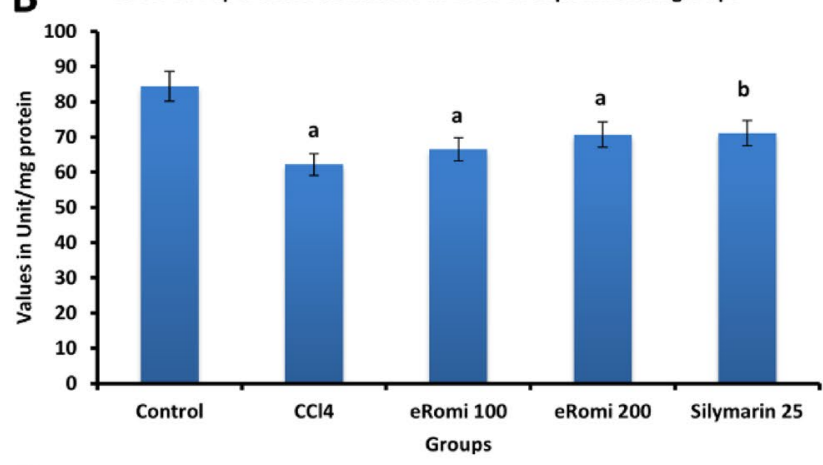

D

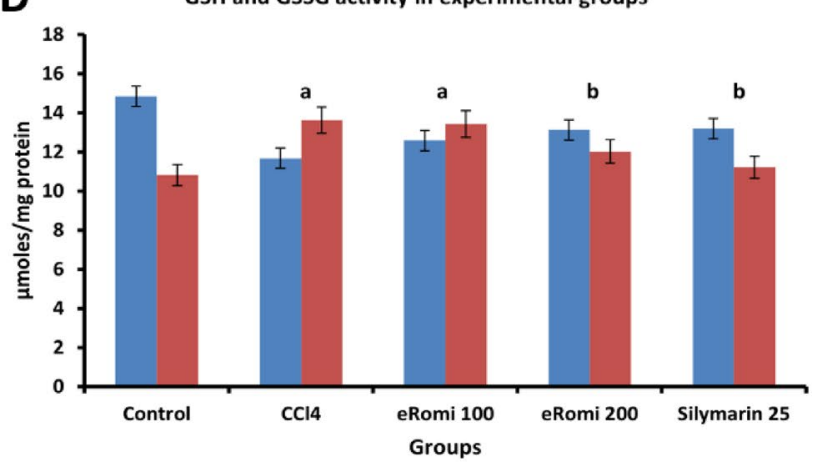

by one-way ANOVA between groups and values were considered significant at $p<0.05$. Those which are not sharing the same letters are significantly different

\subsubsection{Effect of eRoMi on lipid peroxidation}

Lipid peroxidation was accessed by evaluating the level of MDA and was expressed in $\mathrm{nmol} / \mathrm{mg}$ of protein. Figure 4 shows the effects of eRoMi treatment on the $\mathrm{CCl}_{4}$-induced alteration of MDA level. The MDA content was significantly elevated by $69 \%$ in the $\mathrm{CCl}_{4}$-treated group compared with that of the control group $(p<0.05)$. However, treatment with eRoMi and silymarin significantly reduced MDA level, and eRoMi at high concentration ( $200 \mathrm{mg} / \mathrm{kg} \mathrm{BW}$ ) markedly relieved the $\mathrm{CCl}_{4}$-induced elevation in the lipid peroxidation $(p<0.05)$. 
Fig. 3 Effect of eRoMi on GSH/ GSSG ratio (GSH metabolism). Values are mean \pm S.E. $(n=6$ animals per group). Statistical analysis was done by one-way ANOVA between groups and values were considered significant at $p<0.05$. Those which are not sharing the same letters are significantly different

\section{GSH/GSSH activity in experimental groups}

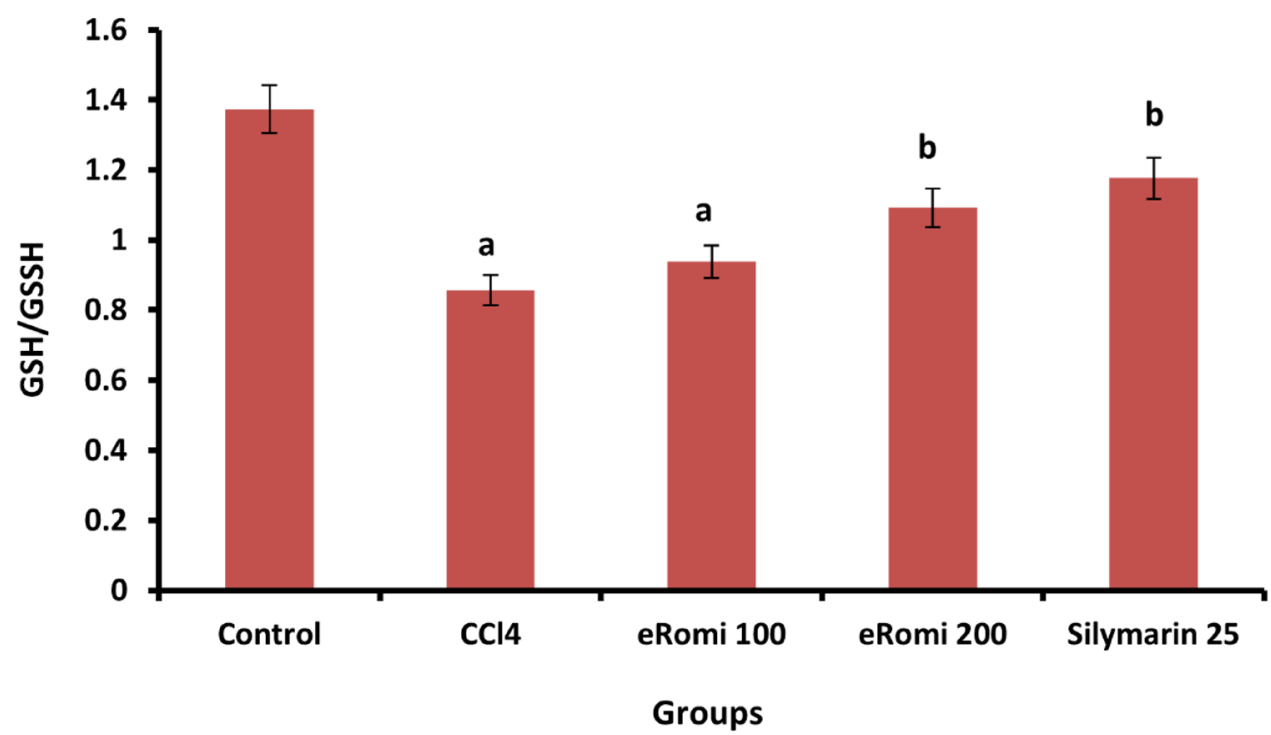

\subsubsection{Effect of eRoMi on histopathological changes}

Histopathological evaluation of the rat livers (Table S3; Fig. 5) showed that the hepatocytes of a healthy rat (from the control group) had a normal architecture (Fig. 5a), whereas, in contrast, $\mathrm{CCl}_{4}$ induced severe hepatocyte necrosis, inflammation, and hemorrhage (Fig. 5b). After treatment with eRoMi, the severity of $\mathrm{CCl}_{4}$-induced liver intoxication was reduced in a dose-dependent manner (Fig. $5 \mathrm{c}$ and $5 \mathrm{~d}$ ), although the treatment with silymarin showed better result (Fig. 5e).

\section{Discussion}

$\mathrm{CCl}_{4}$ is a classic compound commonly used for xenobiotic-induced hepatic injury of the liver to understand the pathogenesis of hepatic steatosis in the experimental animal models $[39,11]$. The liver injury is due to the reactive oxygen species (ROS)-induced oxidative stress that can generate toxic lipid intermediates. Weber et al. [40] understood in their study that $\mathrm{CCl}_{4}$ ingestion activates cytochrome system (i.e., CYP2E1) and forms trichloromethyl radicals $\left(\mathrm{CCl}_{3+}\right)$. It becomes toxic because of a reactive intermediate generated by its reductive metabolism, and this highly reactive intermediate is known to induce leakage of serum enzymes, lipid peroxidation, depletion
Fig. 4 Effect of eRoMi on lipid peroxidation (the level of MDA). ${ }^{*}$ Values are mean \pm S.E. ( $n=6$ animals/group). Statistical analysis was done by oneway ANOVA between groups and values were considered significant at $p<0.05$. Those which are not sharing the same letters are significantly different
Level of Malondialdehyde in Liver of experimental groups

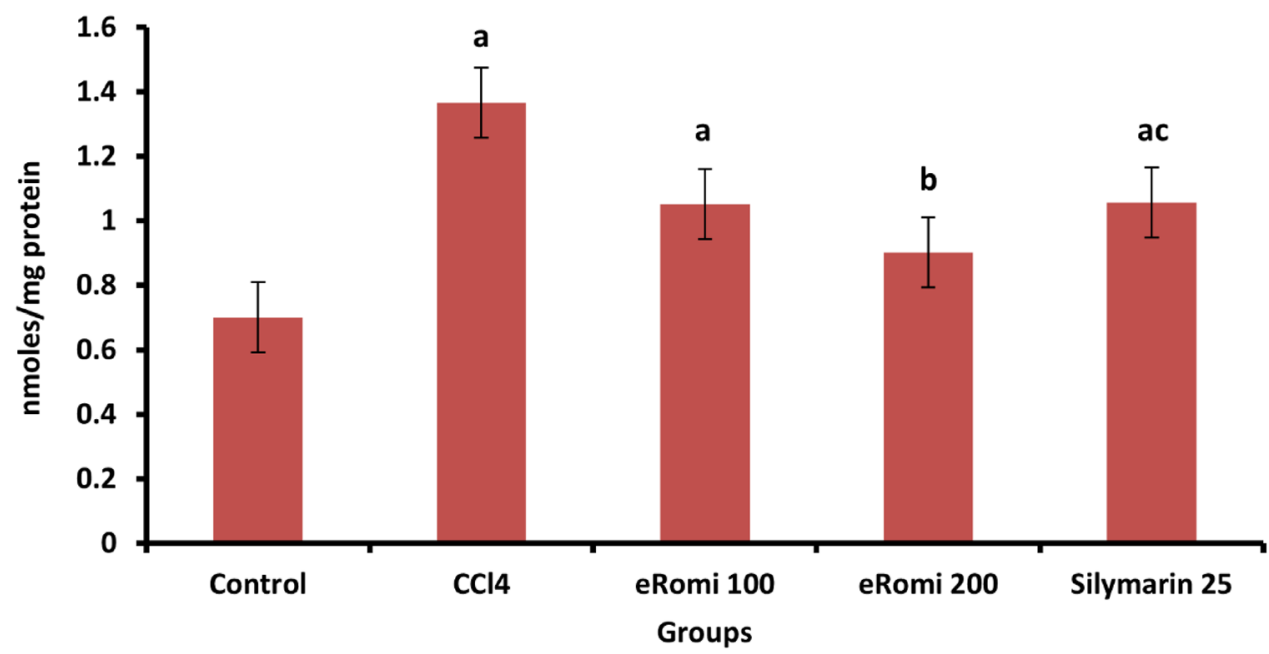


Fig. 5 Histopathologic section of liver $(400 \mathrm{X})$ with hematoxylin and eosin staining the cell nucleus and cytoplasm with extracellular matrix with purple blue and pink colours, respectively: a Showing normal arrangement of hepatocytes in the liver lobule. b Showing hepatocyte necrosis, inflammation, biliary cirrhosis, microvesicular steatosis, broad infiltration of Kupffer cells around the central vein and vacuolation in $\mathrm{CCl}_{4}$ treated wistar rats. c Animal treated with $\mathrm{CCl}_{4}$ and $100 \mathrm{mg} / \mathrm{kg}$ RoMi showing mild sinusoidal dialatation in centrizonal area, necrosis recovery around the central vein and hepatocytes showing regenerative activity. d Animal treated with $\mathrm{CCl}_{4}$ and $200 \mathrm{mg} / \mathrm{kg}$ RoMi showing no centrilobular necrosis, hepatocytes with normal texture around the central vein and proper sinusoid texture. $\mathbf{e}$ $\mathrm{CCl}_{4}$ and silymarin $(25 \mathrm{mg} / \mathrm{kg})$ treated animals showing normal hepatocytes and proper central vein. (NB: CV: Central vein, BC: Biliary cirrhosis, V: vacuolation, II: Inflammatory infiltration, MS: Microvesicular steatosis, MN: Mild necrosis and $\mathrm{RH}$ : Regenerating hepatocyte)
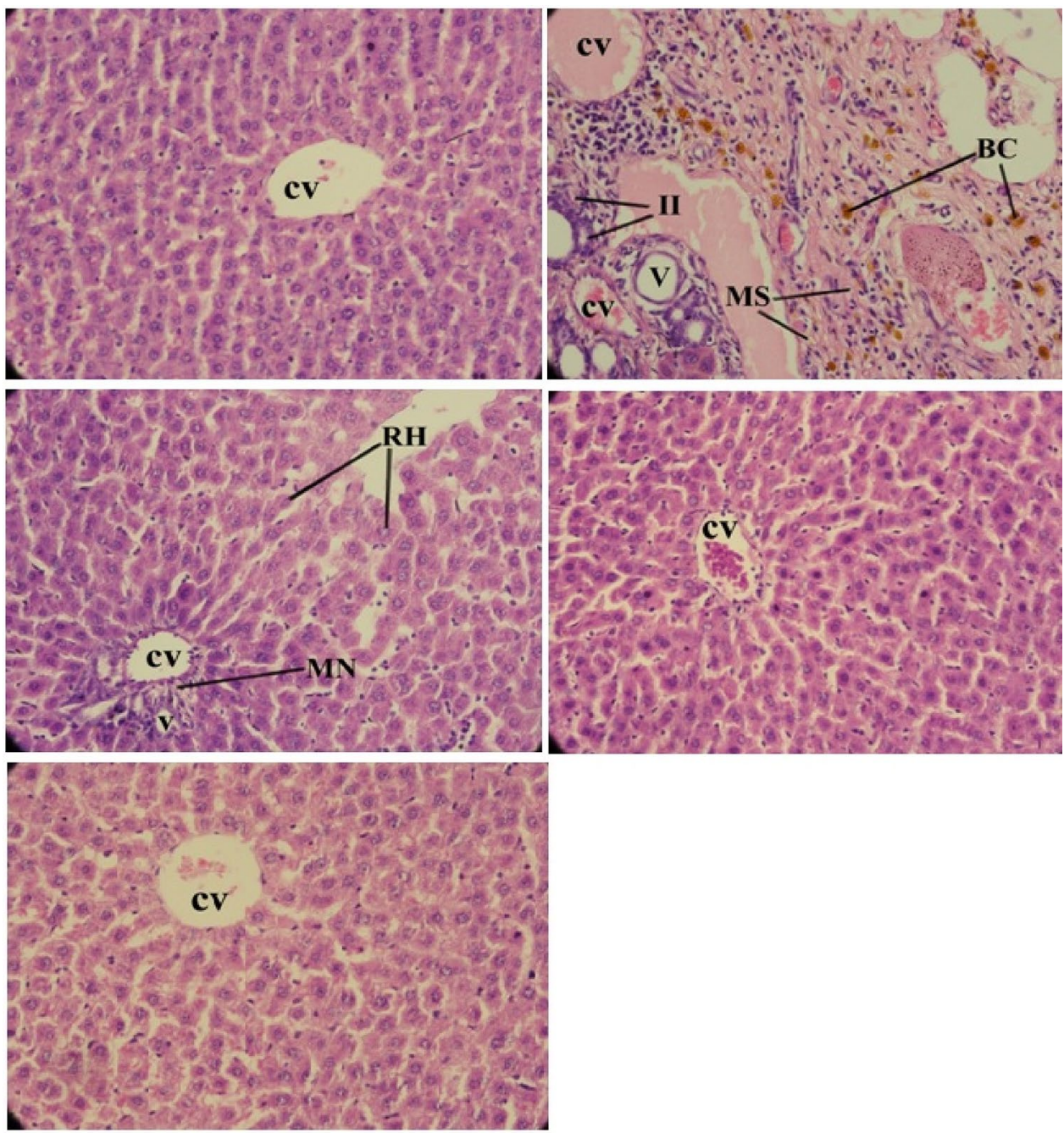

of antioxidant capacity and hepatic necrosis around the central vein [25].

Prior studies have reported that herbal and medicinal plants substantially contribute to the treatment of cholestatic disorder or hepatocellular insult and liver injury [41]. In the present study, we show that the ethanolic root extracts of $\mathrm{M}$. indica can significantly prevent $\mathrm{CCl}_{4}$-induced acute liver damage. Among all the detected compounds in eRoMi by GC-MS analysis, a-amyrin is known to be three times more potent in its anti-inflammatory effect than aspirin [38]. 1,2-Bis (trimethylsilyl) benzene, 1,4-phenylenebis (trimethylsilane), 2,4,6-cycloheptatriene-1-one, and 3,5-bis-trimethylsilyl were other novel compounds that were detected for the first time in eRoMi. Serum marker enzymes, such as AST, ALT, ALP, and GGT are recognized as liver marker enzymes that exhibit increased activities when the liver cells are necrotic, during cholestatic disorder or hepatocellular insult [42]. Wills and Asha [43] signified in their study that after liver injures, AST and ALT progresses from the cytoplasm to the circulatory system because of the toxicity mediated transformed permeability of the cellular membrane. Additionally, there are other important indices to evaluate the hepatic function, such as TC, TG, HDL, LDL, VHDL, total protein and albumin levels in serum. Our in-vivo study demonstrated that the $\mathrm{CCl}_{4}$-induced control group had a significant increase in the activities of liver indices suggesting acute cellular damage. Many authors have also reported that the activities of serum enzymes and other indices were significantly elevated after inducing $\mathrm{CCl}_{4}$ in animals [44], 45, 46]. On the other hand, daily administration of eRoMi to $\mathrm{CCl}_{4}$-induced hepatotoxic rats attenuated the increased activity of liver marker enzymes and alleviated the loss of functional integrity of the cell membrane, indicating its hepatoprotective activity. eRoMi at $200 \mathrm{mg} / \mathrm{kg}$ dose was able to reduce the levels of these serum enzymes comparable to the standard drug silymarin, which showed a better index, though not significant. Our results are in agreement with the findings from previous studies where the hepatoprotective activities of the leaf extracts of Morus indica and

\section{SN Applied Sciences


Morus alba L. against $\mathrm{CCl} 4$ treatment were reported to decrease the serum levels of AST and ALT in rat and mice models, respectively $[25,26]$.

Further, the hematological parameters were assessed to check the acute effects of the test extract. Hematological parameters are significant in establishing the body's functional status as a result of exposure to drugs [47]. Treatment of eRoMi caused no significant changes in the levels of major hematological indices such as erythrocyte count, hemoglobin, leukocytes, and MCHC. However, a reduction in $\mathrm{MCH}$ was observed, suggesting the possibility of anemia. The lymphocytes and monocytes count were also reduced in the eRoMi-treated groups as compared to the normal group. Although eRoMi had no major significant effect on most of the hematological parameters in rats, it could be concluded that the use of this extract should be with some cautious measures to avoid anemia and other immunological dysfunctions. Specific hematological and immunotoxicological studies are thus warranted in the future to fully understand the effect of eRoMi on all the immune cell types.

Electrolytes are generally described as the ionized or ionizable minerals of a living cell, blood, or other organic matter. Sodium $\left(\mathrm{Na}^{+}\right)$, potassium $\left(\mathrm{K}^{+}\right)$, and chloride $\left(\mathrm{Cl}^{-}\right)$are important blood electrolytes. These electrolytes carry electric charges in liquid media like blood. They participate in several functions that help in regulating nerve and muscle functions and maintain acid-base balance and water balance [48]. Imbalance in these electrolytes can cause electrolyte abnormalities. A study conducted by Salihu et al. [49] observed that $\mathrm{CCl}_{4}$ causes an imbalance in the major blood electrolytes. The present study shows that $\mathrm{CCl}_{4}$ increases the levels of electrolytes. Upon treatment with eRoMi, a decrease in these levels was observed; however, were not significant, suggesting that there were no electrolyte abnormalities. Blood urea and creatinine are important parameters indicating the health of both the liver and the kidneys. Blood urea is a waste product of protein metabolism, synthesized in the liver and excreted by the kidney [48]. Creatinine is a by-product of muscle metabolism excreted unchanged by the kidneys, making it an important indicator of renal health. The results of the present study showed that the level of blood urea increased in $\mathrm{CCl}_{4}$-intoxicated rats indicating renal damage. Upon treatment with eRoMi, the blood urea level decreased and there was no significant change in creatinine.

Furthermore, the histopathological examination of the liver provided evidence of the effects of investigated components against acute $\mathrm{CCl}_{4}$-induced liver injury, which also substantiated the biochemical analysis. The histology showed that $\mathrm{CCl}_{4}$ administration caused serious oxidative liver damage characterized by severe necrosis, inflammation, hepatocellular degeneration, cytoplasmic vacuolation and loss of cellular boundaries, which are in conformity with the previous studies for the liver injury $[40,50,51]$. Treatment with eRoMi was noteworthy in a dose-dependent manner as it reduced the severity caused due to oxidative damage. This was evidenced by a decrease in necrosis and hemorrhage (Fig. 5). Hence, it indicates the protection provided by the administration of eRoMi. The high dose of eRoMi induced an effect close to normal emergence, recommending that the high dose of $200 \mathrm{mg} / \mathrm{kg}$ was more effective than the low dose $(100 \mathrm{mg} /$ $\mathrm{kg}$ ). This was in concordance with the results of serum biochemical markers analysis. The antioxidant enzymes, such as CAT, SOD and GPx are the endogenous enzymes that form an imperative part of the antioxidant defense system. They detoxify the free radicals and thus protect the hepatic cells against oxidant-mediated injury. Treatment with $\mathrm{CCl}_{4}$ alone can deplete the activity of these enzymes. It also depletes the hepatic GSH system, a key component of the overall antioxidant defense system and can also cause lipid peroxidation resulting in liver cirrhosis $[32,52]$. The decline in the levels of the antioxidant enzyme activities (CAT, SOD and GPx) and GSH level observed in $\mathrm{CCl}_{4}$-treated rats is a clear indicator of excessive formation of hepatic lipid peroxidation in comparison to the normal group. This fact has also been reported in previous studies $[32,50,53]$. On the contrary, the groups treated with eRoMi at two different doses significantly increased CAT, SOD and GPx activities, increased GSH contents and reduced the MDA content (or the lipid peroxidation level) in the liver. A decrease in ROS production seen in the liver could be the result of counter enzymes production such as SOD, GPx, and GSH in eRoMi-supplemented groups. In addition, a decrease in LPx in biological membranes was reported to be directly linked with increased GPx activity [54]. Therefore, the commencement of cellular antioxidant defense could be one of the foremost mechanisms for the disease-preventing outcome of eRoMi. The preventive effect of eRoMi at $200 \mathrm{mg} / \mathrm{kg}$ was similar to that of silymarin treatment. The overall scheme of possible hepatoprotective effects by eRoMi was presented in Fig. 6 . Schematic representation indicates the role of $\mathrm{CCl}_{4}$ in the induction of hepatotoxicity and the possible protective role of eRoMi in reducing the hepatotoxicity. Thus, in conclusion, the present study provides scientific evidence in favor of the pharmacological use of the roots of $M$. indica as an effective alternative in the treatment of liver disorders.

Acknowledgements HB is obliged to DST for providing Rajiv Gandhi Fellowship, Govt of India. SKM is grateful to the DST-FIST facility (F.No. SR/FST/ 404/2018) under the Government of India, Biotechnology Skill Enhancement Program (BiSEP) under Government of Karnataka and management, Maharani Lakshmi Ammanni College for Women $(\mathrm{mLAC})$, for providing animal facilities. 


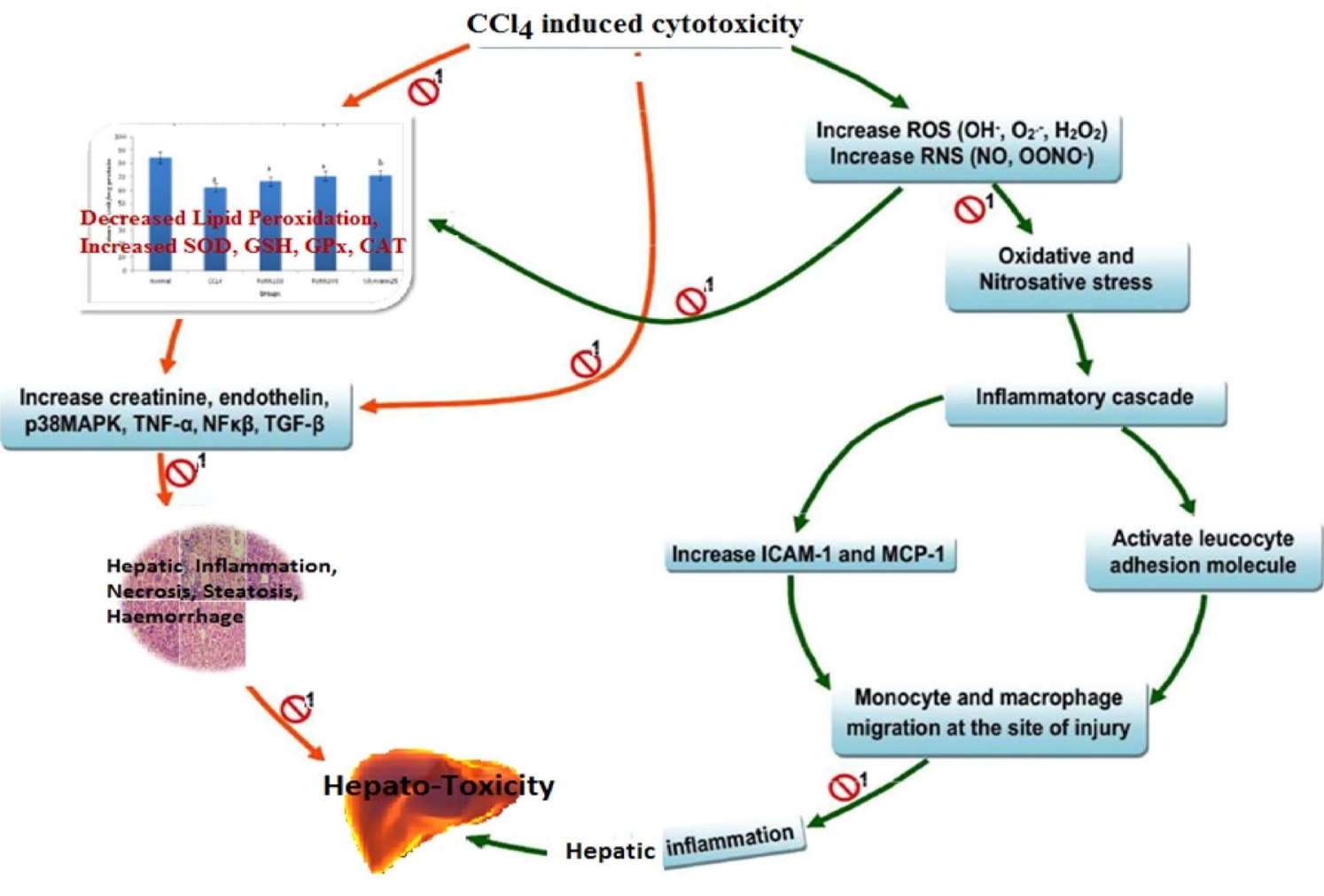

Fig. 6 Schematic representation showing the role of $\mathrm{CCl}_{4}$ in the induction of hepatotoxicity and the possible role of the ethanolic extract of the roots of Morus indica L. (eRoMi) showing the hepatoprotective activity

Author contributions $\mathrm{HB}, \mathrm{PC}$, and TU contributed to performing the laboratory work and partially wrote the manuscript. TU, HE contributed to the estimation of the chemical composition. HSY, AKG, DB contributed to analysing the data, drafting and language editing of the manuscript. SKM and SD conceived the idea, supervised the laboratory work and contributed to the critical reading of the manuscript. All the authors have read and approved the manuscript for its final submission.

\section{Declarations}

Conflict of interest The authors declare no conflict of interest.

Ethical statement All the experiments were performed in strict accordance with standard guidelines accepted internationally, and the ethical approval was obtained from Maharani Lakshmi Ammanni College Ethical Committee (1368/ac/10/CPCSEA), Bangalore, for the care and use of laboratory animals.

Open Access This article is licensed under a Creative Commons Attribution 4.0 International License, which permits use, sharing, adaptation, distribution and reproduction in any medium or format, as long as you give appropriate credit to the original author(s) and the source, provide a link to the Creative Commons licence, and indicate if changes were made. The images or other third party material in this article are included in the article's Creative Commons licence, unless indicated otherwise in a credit line to the material. If material is not included in the article's Creative Commons licence and your intended use is not permitted by statutory regulation or exceeds the permitted use, you will need to obtain permission directly from the copyright holder. To view a copy of this licence, visit http://creativecommons. org/licenses/by/4.0/.

\section{References}

1. Ishibashi H, Nakamura M, Komori A, Migita K, Shimoda S (2009) Liver architecture cell function and disease. Seminars Immunopathol 31:399-409

2. Cicek T, Gokturk HS, Unler GK (2015) Acute hepatocellular drug induced liver injury probably by alfuzosin. Case Rep Urol. Artcile ID: 101062

3. Chaudhury A, Duvoor C, Dendi R, Sena V, Kraleti S, Chada A, Ravilla R, Marco A, Shekhawat NS, Montales MT, Kuriakose K (2017) Clinical review of antidiabetic drugs: implications for type 2 diabetes mellitus management. Front Endrocrinol 8:6

4. Giacometti J, Muhvić D, Pavletić A, Đudarić L (2016) Cocoa polyphenols exhibit antioxidant anti-inflammatory anticancerogenic and anti-necrotic activity in carbon tetrachloride-intoxicated mice. J Funct Food 23:177-187

5. Kamala A, Middha SK, Karigar CS (2018) Plants in traditional medicine with special reference to Cyperus rotundus $\mathrm{L}$.: a review. 3 Biotech 8:309

6. Madrigal-Santillán E, Madrigal-Bujaidar E, Álvarez-González I, Sumaya-Martínez MT, Gutiérrez-Salinas J, Bautista M, MoralesGonzález ÁY, González-Rubio MGL, Aguilar-Faisal JL, MoralesGonzález JA (2014) Review of natural products with hepatoprotective effects. World J. Gastroentero: WJG 20(40):14787

\section{SN Applied Sciences}


7. Quan M, Li Q, Zhao P, Tian C (2018) Chemical composition and hepatoprotective effect of free phenolic extract from barley during malting process. Sci Rep 8(1):1-9

8. Dey SK, Middha SK, Usha T, Brahma BK, Goyal AK (2018) Antidiabetic activity of giant grass Bambusa tulda. Bangladesh J Pharmacol 13(2):134-135

9. Goyal AK, Middha SK, Usha T (2020) Baccaurea ramiflora Lour.: a comprehensive review from traditional usage to pharmacological evidence. Adv Tradit Med. Doi: 10.1007\%2Fs13596-020-00489-9

10. Goyal AK, Middha SK, Usha T, Sen A (2017) Analysis of toxic antidiabetic and antioxidant potential of Bambusa balcooa Roxb leaf extracts in alloxan-induced diabetic rats. 3 Biotech 7(2):120

11. Ma T, Sun X, Tian C, Zheng Y, Zheng C, Zhan J (2015) Chemical composition and hepatoprotective effects of polyphenols extracted from the stems and leaves of Sphallerocarpus gracilis. J Funct Food 8:673-683

12. Middha SK, Usha T, Basistha BC, Goyal AK (2019) Amelioration of antioxidant potential, toxicity, and antihyperglycemic activity of Hippophae salicifolia D. Don leaf extracts in alloxan-induced diabetic rats. 3 Biotech 9:308

13. Scalbert A, Manach C, Morand C, Rémésy C, Jiménez L (2005) Dietary polyphenols and the prevention of diseases. Crit Rev Food Sci 45(4):287-306

14. Usha T, Pradhan S, Goyal AK, Dhivya S, Kumar HP, Singh MK, Joshi N, Basistha BC, Murthy KS, Selvaraj S, Middha SK (2017) Molecular simulation-based combinatorial modeling and antioxidant activities of zingiberaceae family rhizomes. Phcog Mag 13(Suppl 3):S715

15. da Silva Almeida JRG, Souza GR, da Cruz Araújo EC, Silva FS, de Lima JT, de Araújo Ribeiro LA, Nunes XP, Barbosa Filho JM, Júnior LJQ, dos Santos MRV (2012) Medicinal plants and natural compounds from the genus Morus (Moraceae) with hypoglycemic activity: a review. Glucose Tolerance 189-206. IntechOpen

16. Usha T, Middha SK, Bhattacharya M, Lokesh P, Goyal AK (2014) Rosmarinic Acid a New Polyphenol from Baccaurea ramiflora Lour Leaf: A Probable Compound for Its Anti-Inflammatory Activity. Antioxidants 3(4):830-842

17. Chopra RN, Chopra IC, Handa KL, Kapur LD (1958) Chopra's indigenous drugs of India, Second Ed., Calcutta UN Dhar and Sons Pvt Ltd

18. Konno C, Oshima Y, Hikino H (1977) Morusinol isoprenoid flavone from Morus root barks. Planta Med 32(06):118-124

19. Chatterjee GK, Burman TK, Nagchaudhuri AK, Pal SP (1983) Antiinflammatory and antipyretic activities of Morus indica. Planta Med 48(06):116-119

20. Wei H, Zhu JJ, Liu XQ, Feng WH, Wang ZM, Yan LH (2016) Review of bioactive compounds from root barks of Morus plants (SangBai-Pi) and their pharmacological effects. Cogent Chem. 2(1): Article ID 1212320

21. Andallu B, Varadacharyulu N (2003) Antioxidant role of mulberry (Morus indica L cv Anantha) leaves in streptozotocin-diabetic rats. Clin Chim Acta 338(1-2):3-10

22. Natić MM, Dabić DČ, Papetti A, Akšić MMF, Ognjanov V, Ljubojević M, Tešić ŽL (2015) Analysis and characterisation of phytochemicals in mulberry (Morus alba L.) fruits grown in Vojvodina North Serbia. Food Chem 171:128-136

23. Asano N, Yamashita T, Yasuda K, Ikeda K, Kizu H, Kameda Y, Kato A, Nash RJ, Lee HS, Ryu KS (2001) Polyhydroxylated alkaloids isolated from mulberry trees (Morus alba L) and silkworms (Bombyx mori L ). J Agric Food Chem 49(9):4208-4213

24. Singh R, Bagachi A, Semwal A, Kaur S, Bharadwaj A (2013) Traditional uses phytochemistry and pharmacology of Morus alba Linn: a review. J Med Plant Res 7(9):461-469
25. Kalantari H, Aghel N, Bayati M (2009) Hepatoprotective effect of Morus alba $\mathrm{L}$ in carbon tetrachloride-induced hepatotoxicity in mice. Saudi Pharma J 17(1):90-94

26. Reddy VP, Urooj A (2017) Evaluation of hepatoprotective activity of Morus indica Linn against toxicity induced by carbon tetrachloride in rats. Int J Pharma Sci Res 8(2):845

27. Tag HM (2015) Hepatoprotective effect of mulberry (Morus nigra) leaves extract against methotrexate induced hepatotoxicity in male albino rat. BMC Complement Altern Med 25(15):252

28. Jin YS, Lee MJ, Han W, Heo SI, Sohn SI, Wang MH (2006) Antioxidant effects and hepatoprotective activity of 25 -dihydroxy-4 3'-di ( $\beta$-d-glucopyranosyloxy)-trans-stilbene from Morus bombycis Koidzumi roots on $\mathrm{CCl}_{4}$-induced liver damage. Free Rad Res 40:986-992

29. Abdel-Aal ESM, Choo TM, Dhillon S, Rabalski I (2012) Free and bound phenolic acids and total phenolics in black blue and yellow barley and their contribution to free radical scavenging capacity. Cereal Chem 89(4):198-204

30. Middha SK, Usha T, Babu D, Misra AK, Lokesh P, Goyal AK (2016) Evaluation of antioxidative analgesic and anti-inflammatory activities of methanolic extract of Myrica nagi leaves-an animal model approach. Symbiosis 70(1-3):179-184

31. Misra HP, Fridovich I (1972) The role of superoxide anion in the autoxidation of epinephrine and a simple assay for superoxide dismutase. J Biol Chem 247(10):3170-3175

32. Khan RA, Khan MR, Ahmed M, Sahreen S, Shah NA, Shah MS, Bokhari J, Rashid U, Ahmad B, Jan S (2012) Hepatoprotection with a chloroform extract of Launaea procumbens against $\mathrm{CCl}$ 4-induced injuries in rats. BMC Comp Alt Med 12(1):114

33. Middha SK, Bhattacharjee B, Saini D, Baliga MS, Nagaveni MB, Usha T (2011) Protective role of Trigonella foenum graceum extract against oxidative stress in hyperglycemic rats. Eur Rev Med Pharmacol Sci 15(4):427-435

34. Salbitani G, Bottone C, Carfagna S (2017) Determination of reduced and total glutathione content in extremophilic microalga Galdieria phlegrea. Bio-Protocol 7:e2372

35. Griffith OW (1980) Determination of glutathione and glutathione disulfide using glutathione reductase and 2-vinylpyridine. Anal Biochem 106(1):207-212

36. Lowry OH, Rosebrough NJ, Farr AL, Randall RJ (1951) Protein measurement with the Folin phenol reagent. J Biol Chem 193:265-275

37. Ohkawa H, Ohisi N, Yagi K (1979) Assay of Lipid peroxidation in animals and tissues by thiobarbituric acid test. Anal Biochem 95:351-358

38. Raman BV, Samuel LA, Saradhi MP, Rao BN, Krishna NV, Sudhakar M, Radhakrishnan TM (2012) Antibacterial antioxidant activity and GC-MS analysis of Eupatorium odoratum. Asian J Pharma Clinic Res 5(2):99-106

39. Chen J, Sun H, Sun A, Hualin Q, Wang Y, Tao X (2012) Studies of the protective effect and antioxidant mechanism of blueberry anthocyanins in a CC14-induced liver injury model in mice. Food Agric Immunol 23(4):352-362

40. Weber LW, Boll M, Stampfl A (2003) Hepatotoxicity and mechanism of action of haloalkanes: carbon tetrachloride as a toxicological model. Crit Rev Toxicol 33(2):105-136

41. Balaban YH, Aka C, Koca-Caliskan U (2017) Liver immunology and herbal treatment. World J Hepatol 9(17):757-770

42. Agganis B, Lee $D$, Sepe $T$ (2018) Liver enzymes: no trivial elevations even if asymptomatic. Clevel Clin J Med 85(8):612-617

43. Wills PJ, Asha VV (2006) Protective effect of Lygodium flexuosum (L.) Sw. extract against carbon tetrachloride-induced acute liver injury in rats. J Ethnopharmacol 108(3):320-326

44. Karakus E, Karadeniz A, Simsek N, Can I, Kara A, Yildirim S, Kalkan Y, Kisa F (2011) Protective effect of Panax ginseng against serum 
biochemical changes and apoptosis in liver of rats treated with carbon tetrachloride $\left(\mathrm{CCl}_{4}\right)$. J Hazard Matter 195:208-213

45. Srivastava A, Shivanandappa T (2006) Hepatoprotective effect of the aqueous extract of the roots of Decalepis hamiltonii against ethanol-induced oxidative stress in rats. Hepatol Res 35(4):267-275

46. Tang XH, Gao J, Chen J, Xu LZ, Tang YH, Zhao XN, Michael L (2008) Mitochondrial modulation is involved in the hepatoprotection of Limonium sinense extract against liver damage in mice. J Ethnopharmacol 20(3):427-431

47. Ladokun O, Ojezele M, Arojojoye O (2015) Comparative study on the effects of aqueous extracts of viscum album (mistletoe) from three host plants on hematological parameters in albino rats. Afr Health Sci 15(2):606-612

48. Bakour M, Soulo N, Hammas N, Fatemi HE, Aboulghazi A, Taroq A, Abdellaoui A, Al-Waili N, Lyoussi B (2018) The antioxidant content and protective effect of argan oil and Syzygium aromaticum essential oil in hydrogen peroxide-induced biochemical and histological changes. Int J Mol Sci 19(2):610

49. Salihu M, Akpabio CJ, Oloyede OB, Mohammed NO (2013) Effect of determined mineral elements in mesocarp of Balanites Aegyptiaca fruit on serum electrolytes of $\mathrm{CCl}_{4}$ treated Rats. IOSR J Pharm Biol Sci 7:86-90

50. Maheshwari DT, Kumar MY, Verma SK, Singh VK, Singh SN (2011) Antioxidant and hepatoprotective activities of phenolic rich fraction of Seabuckthorn (Hippophae rhamnoides L.) leaves. Food Chem Toxicol 49(9):2422-2428

51. Vuda M, D'Souza R, Upadhya S, Kumar V, Rao N, Kumar V, Boillat C, Mungli P (2012) Hepatoprotective and antioxidant activity of aqueous extract of Hybanthus enneaspermus against $\mathrm{CCl}_{4}$-induced liver injury in rats. Exp Toxicol Pathol 64(7-8):855-859

52. Lin HM, Tseng HC, Wang CJ, Lin JJ, Lo CW, Chou FP (2008) Hepatoprotective effects of Solanum nigrum Linn extract against $\mathrm{CCl}_{4}$-iduced oxidative damage in rats. Chem Biol Interact $171(3): 283-293$

53. Tung $\mathrm{YT}$, Wu JH, Huang $\mathrm{CC}$, Peng HC, Chen $\mathrm{YL}$, Yang SC, Chang ST (2009) Protective effect of Acacia confusa bark extract and its active compound gallic acid against carbon tetrachloride-induced chronic liver injury in rats. Food Chem Toxicol 47(6):1385-1392

54. Upreti K, Misro MM (2002) Evaluation of oxidative stress and enzymatic antioxidant activity in brain during pregnancy and lactation in rats. Health Popul Perspect Issues 25(3):105-112

Publisher's Note Springer Nature remains neutral with regard to jurisdictional claims in published maps and institutional affiliations. 